\title{
Sex Differences in Mercury Contamination of Birds: Testing Multiple Hypotheses with Meta-Analysis
}

\author{
Stacey A. Robinson, ${ }^{*}{ }^{\dagger}$ Marc J. Lajeunesse, ${ }^{\ddagger}$ and Mark R. Forbes ${ }^{\dagger}$ \\ ${ }^{\dagger}$ Department of Biology, Carleton University, 209 Nesbitt Building, 1125 Colonel By Drive, Ottawa, Ontario, K1S 5B6, Canada \\ ${ }^{\ddagger}$ Department of Integrative Biology, University of South Florida, SCA 110, 4202 East Fowler Avenue, Tampa, Florida 33620-5200, \\ United States
}

Supporting Information

ABSTRACT: The sex of a bird can, in principle, affect exposure and accumulation of mercury. One conventional explanation for sex differences in mercury burden suggests female birds should have lower concentrations than conspecific males, because breeding females can depurate methylmercury to their eggs. However, sex differences in body burden of mercury among birds are not consistent. We used meta-analysis to synthesize 123 male-female comparisons of mercury burden from 50 studies. For breeding birds, males had higher concentrations of mercury than did females, supporting egg depuration as a mechanism. However, the percentage of female body mass represented by a clutch did not significantly predict the magnitude of the sex difference in mercury contamination, as predicted. Furthermore, whether species were semialtrical or altrical versus semiprecocial or precocial also did not explain sex differences in mercury burden. Foraging guild of a species did explain near

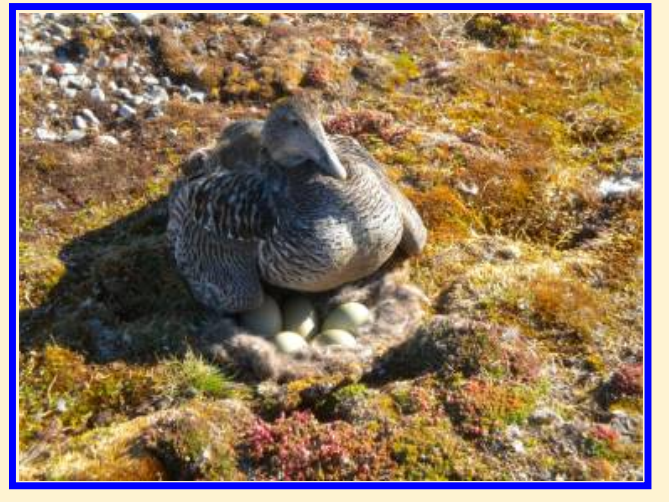
significant variation in sex differences in mercury burden where piscivores and invertivores showed significant sex differences, but sex differences were not detected for carnivores, herbivores, insectivores, and omnivores. The magnitude and direction of sexual size dimorphism did not explain variation in sex differences in mercury burden among breeding birds. We reveal targeted research directions on mechanisms for sex differences in mercury and confirm that sex is important to consider for environmental risk assessments based on breeding birds.

\section{INTRODUCTION}

Risks to populations of free-ranging wildlife can be monitored by measuring tissue levels and adverse effects of contaminants. Mercury is a toxic heavy metal of increasing global concern that has been extensively monitored. ${ }^{1,2}$ Birds are useful for studies on biomonitoring of mercury because they accumulate mercury in their tissues, are found in a variety of habitats, and are readily visible allowing them to be tracked, monitored, and sampled relatively easily. Furthermore, birds have a large amount of public appeal and awareness and thus receive strong support for their health and conservation.

Biomonitoring studies have routinely not reported the sex of the birds when analyzing metal concentrations. ${ }^{3}$ Representation of males and females in samples could affect the concentrations of metals reported and their effects seen in birds because males and females differ in their physiology, morphology, and behavior. All of these differences can influence exposure, uptake, and accumulation of metals. ${ }^{3}$ Several researchers have stated that it is imperative to understand how sex influences tissue concentrations and adverse effects of metals in organisms. Such an understanding is important for effectively protecting and managing wildlife populations, recognizing early warning signals of potential population effects, and choosing certain species as bioindicators of human effects. ${ }^{3-6}$
Birds are exposed to the most toxic, bioaccumulating, and biomagnifying form of mercury (methylmercury) primarily through their food, where exposure can increase with trophic level. ${ }^{1}$ Breeding birds often show male biases in concentrations of mercury, often explained by the fact that females depurate methylmercury to their eggs: a route of excretion males lack (Table 1). ${ }^{7,8}$ This conventional explanation is widespread. However, consistent significant sex differences in mercury concentration are not evident. ${ }^{3}$ Furthermore, theoretical models have not consistently shown that egg depuration can account fully for the sex difference in the concentration of mercury. ${ }^{8-10}$ Additionally, experimental work where input and output of mercury was monitored could not support that egg depuration was the entire explanation for the resulting sex difference in mercury concentration. ${ }^{11}$ Therefore, although the conventional explanation suggests females depurate methylmercury to their eggs and consequently reduce their methylmercury body burden relative to males, the inconsistencies in the literature suggest a more thorough under-

Received: November 11, 2011

Revised: $\quad$ May 24, 2012

Accepted: June 5, 2012

Published: June 5, 2012 
Table 1. Primary (I) and Ancillary (II, III) Hypotheses and Their Predictions for Sex Differences in the Concentration of Mercury (Hg) in Birds

\begin{tabular}{|c|c|}
\hline hypothesis & prediction(s) \\
\hline (I) Depuration of $\mathbf{H g}$ to eggs, as males lack this excretion route ${ }^{7,8}$ & $\begin{array}{l}\text { (i) Breeding birds: male }[\mathrm{Hg}]>\text { female }[\mathrm{Hg}] \text {; Nonbreeding birds: male }[\mathrm{Hg}]= \\
\text { female }[\mathrm{Hg}]\end{array}$ \\
\hline & $\begin{array}{l}\text { (ii) Breeding birds: significant positive relationship between Hedges' } d \text { effect } \\
\text { size and the percentage of female body mass represented by a clutch }\end{array}$ \\
\hline $\begin{array}{l}\text { (II) Sexual size dimorphism influences exposure to } \mathrm{Hg} \text {, as ceteris paribus the larger } \\
\text { sex could consume larger prey which often have higher }[\mathrm{Hg}] \text { than smaller prey }\end{array}$ & $\begin{array}{l}\text { Males larger than females: male }[\mathrm{Hg}]>\text { female }[\mathrm{Hg}] \text {; Females larger than } \\
\text { males: female }[\mathrm{Hg}]>\text { male }[\mathrm{Hg}] ; \text { Males and females similar size: male }[\mathrm{Hg}] \\
=\text { female }[\mathrm{Hg}]\end{array}$ \\
\hline
\end{tabular}

(III) Foraging guild and detoxification adaptation, as piscivores being naturally the most exposed to $\mathrm{Hg}$ might have adapted to tolerate methylmercury toxicity by demethylation $^{1}$

standing of the general pattern and the circumstances producing deviations from that pattern are needed.

We tested primary and ancillary hypotheses proposed to explain sex differences in mercury concentrations in birds. One complicating factor is that there is no standard tissue used to biomonitor mercury. Therefore, we first determined if the tissue analyzed for mercury could influence the detection of a sex difference. Here we wanted to know if detection differed using invasive sampling versus noninvasive sampling of tissues (i.e., liver versus blood). Following assessment of no sampling effects, we tested hypotheses for sex differences in mercury in birds (see Table 1). First, we assessed the most common hypothesis: depuration of mercury into eggs by females. Mercury can be excreted from the body via feces, feathers, and in females' eggs. Therefore, the common prediction is that breeding females have lower body burdens of mercury because they have an additional excretion route, i.e., depuration of mercury into eggs. We further predicted that if depuration of mercury into eggs was the primary explanation for the sex differences then species where females invest a large proportion of their body mass into a clutch would have a larger sex difference in mercury concentration than species where females invest a smaller proportion of their body mass into a clutch. We could not assess renesting propensity for samples of species included in our study, but renesting is expected to have an effect on proportion of body mass that is represented by eggs, and thereby increase the amount of mercury depurated to eggs.

Another common explanation is that the sexes are differentially exposed to mercury because the sexes are dimorphic in size. The larger sex can consume larger prey, which often have higher concentrations of mercury. ${ }^{12}$ Thus, we predict that species with greater degrees of sexual size dimorphism will have larger sex differences in mercury. Finally, an ancillary hypothesis is that birds in particular foraging guilds have adapted to tolerate their respective exposure to mercury. Mercury is a natural heavy metal in the environment and although environmental levels were likely lower prior to industrial release of mercury, fish-eating birds have always been exposed to higher amounts of mercury than those at lower trophic levels. A large part of adapting to tolerate methylmercury includes minimizing exposure to embryos because it is the embryo that is most sensitive to the lethal effects of methylmercury. ${ }^{1}$ Therefore, we expect females of piscivorous species that have been exposed to elevated levels of mercury over evolutionary time to have been selected to detoxify mercury, to a greater extent than males, because females are charged with protecting the embryos. This thinking follows from the premise that seabirds have adapted to tolerate methylmercury by demethylating it to its less toxic form ${ }^{13-15}$ (e.g., piscivores demethylate to a greater extent than invertivores) $)^{15}$ and that highly exposed seabirds depurate minimal amounts of mercury to their eggs. ${ }^{16}$ Thus, species with higher exposure to mercury could at least have the capacity for larger sex differences in mercury. One problem becomes evident and that is that excretion routes such as egg depuration are occurring at the same time of the season (during breeding) as detoxification is occurring, as currently proposed. Thus, finding sex differences in mercury burdens during breeding does not evidence for one hypothesis over another.

\section{METHODS}

Collection of Published Data. We searched for studies analyzing the concentration of mercury in avian tissues through ISI Web of Knowledge using combinations of the following terms: "bird", "mercury", "heavy metal", "contaminant", "waterfowl", "passerine", "piscivore", "sex", and "gender". We considered studies citing or cited by relevant articles retrieved from online database searches. Studies published before June 2011 were considered for inclusion. For a study to be included, authors had to analyze the concentration of mercury in blood or liver separately for adult males and females and report descriptive statistics (i.e., mean, standard deviation (SD) or standard error (SE), sample size). If SD or SE was not reported we imputed the SD for these studies by multiplying the SD to mean ratio (for blood or liver by sex) from complete studies by the mean of the incomplete studies (i.e., the studies requiring the approximated SD). ${ }^{17}$ When only ranges were reported, these were converted to SD following Walter and Yao. ${ }^{18}$

Each comparison was categorized into tissue type (blood, liver, liver/blood); reproductive status (prebreeding, breeding, nonbreeding); hatchling status categorized as semialtricial or altricial versus semiprecocial or precocial; foraging guild (carnivore, herbivore, insectivore, invertivore, omnivore, piscivore); male to female body mass ratio and percentage of the female body mass represented by the clutch (excluding occurrence of renesting). Information on these categories was collected from the original study or The Birds of North America online database, ${ }^{19}$ The Handbook of the Birds of the World series, ${ }^{20}$ CRC Handbook of Avian Body Masses, ${ }^{21}$ and/ or primary literature. Birds were classified as prebreeding, breeding, or nonbreeding based on the information provided in the study. We note that there might be some nonactive breeders included in the breeding samples, but we are unlikely to have included breeders in nonbreeding samples. Comparisons were not included in relevant analysis when the authors did not clearly report breeding status of the birds that were sampled. For analyses based on hatchling status, we treated semialtricial and semiprecocial species as altricial or precocial, respectively. Eggs of precocial species have proportionately more yolk than eggs of altricial species, ${ }^{22}$ which might be 
important because albumen has greater affinity for mercury. ${ }^{23,24}$ When clutch data were reported as ranges, we took the average of these ranges as our overall clutch size. For body size metrics, the ratio of male to female body mass was ln-transformed and thus negative values indicate that female body mass was greater than male body mass for a particular species.

Statistical Analysis. The raw data for the meta-analysis were prepared as follows. The original concentrations of mercury reported in studies were transformed where necessary to $\mu \mathrm{g} / \mathrm{g}$ dry mass concentrations. The concentrations of mercury were converted from wet mass to dry mass by dividing the wet mass concentration by $1-(\%$ moisture $) / 100$. If the authors reported the percent moisture content for the blood or liver tissue then this value was used for the conversion; however, most authors did not report study specific tissue moisture concentrations, so we applied an approximate moisture content for avian blood and liver of $80 \%$ and $70 \%$, respectively. ${ }^{25-27}$

We used Hedges' $d$ as our effect size metric to quantify the difference in mercury concentrations between the means of male $\left(\bar{X}_{\mathrm{M}}\right)$ and female $\left(\bar{X}_{\mathrm{F}}\right)$ groups. This effect size is defined as $d=\left(\bar{X}_{\mathrm{M}}-\bar{X}_{\mathrm{F}}\right) / s$, with $s$ being the pooled standard deviation of $\bar{X}_{\mathrm{M}}$ and $\bar{X}_{\mathrm{F}}{ }^{28}$ We also adjusted $d$ with the small-sample correction factor $J(m)$, where $m=N_{\mathrm{M}}+N_{\mathrm{F}}-2$ and $N$ is the sample size of $\bar{X} .{ }^{29}$ Negative values for $d$ indicate that females had higher concentrations of mercury than males, whereas positive values indicate that males had higher concentrations than females. Studies where $d$ could be calculated for both liver and blood measurements were pooled prior to our overall meta-analysis, assuming that repeated measurements within studies of liver and blood from the same individuals will be correlated. However, studies do not typically report the correlation between liver and blood concentrations of mercury, so we pooled correlations $(r)$ from five published studies using a fixed-effects meta-analysis to estimate a standard correlation between liver and blood concentrations of mercury $(r=0.768$, $N=15 ;^{30} r=0.860, N=35 ;^{31} r=0.775, N=11 ;{ }^{32} r=0.721, N$ $=15 ;{ }^{32} r=0.922, N=115 ;{ }^{27} r=0.922, N=111 ;{ }^{27} r=0.775, N$ $\left.=50 ;{ }^{27} r=0.959, N=115^{27}\right)$. This pooled standard correlation was $\bar{r}=0.914$ (95\% Confidence Interval: 0.894, 0.931). We then used $\bar{r}$ to pool liver (L) and blood (B) effect sizes from the same study by including this correlation in a weighted regression model $^{33}$ with the following covariance equation:

$$
\begin{aligned}
\operatorname{cov}= & \left(\frac{1}{\sqrt{N_{\mathrm{M}}^{\mathrm{L}} N_{\mathrm{M}}^{\mathrm{B}}}}+\frac{1}{\sqrt{N_{\mathrm{F}}^{\mathrm{L}} N_{\mathrm{F}}^{\mathrm{B}}}}\right) \bar{r} \\
& +\frac{d_{\mathrm{L}} d_{\mathrm{B}} \bar{r}^{2}}{2 \sqrt{\left(N_{\mathrm{M}}^{\mathrm{L}}+N_{\mathrm{F}}^{\mathrm{L}}\right)\left(N_{\mathrm{M}}^{\mathrm{B}}+N_{\mathrm{F}}^{\mathrm{B}}\right)}}
\end{aligned}
$$

This covariance equation is the same as that reported in Gleser and Olkin, ${ }^{34}$ but our covariance does not assume that sample sizes are equal among the means of the liver and blood groups.

All meta-analyses and meta-regressions were performed using a random-effects model integrating a DerSimonian-Laird estimator for the between-study variance or $\tau$ (this approach to estimating $\tau$ is the same as MetaWin). ${ }^{35}$ Prior analyses found that the between-study variances for each fixed-effects regression model were significantly nonzero. We further justify our use of random-effects categorical and regression models because we included both descriptive and experimental studies in the data set and the studies were not all done using the same methods (i.e., different sampling protocols, mercury analysis procedures). The between-study variances $(\tau)$ were estimated for each meta-analysis and meta-regression model with the metaphor package in $\mathrm{R},{ }^{36}$ and were added to all the fixed-effects variances for each $d$ (as assumed in random-effects models). ${ }^{37}$ The inverse of this sum was then used as a weighting factor in least-squares regression models run in JMP (v.9). ${ }^{38}$ The regression outputs of JMP are all correct for meta-analysis (e.g., coefficient of determination); however, to fit the assumptions of meta-analysis the significance of regression model factors needs to be evaluated with Chi-square $(Q)$ tests. The regression sums-of-squares for each model factor become these $Q$ values. ${ }^{37}$ The standard errors of the regression parameters are also incorrect, and were adjusted by dividing the SE with the square root of the mean-square residual of the regression model. ${ }^{37}$ These adjusted SE were used to calculate 95\% CI which evaluate nonzero effects among regression slopes and/or pooled effects $(\bar{d})$ among moderator groupings. Finally, $k$ describes the number of $d$ pooled among moderator categories.

\section{RESULTS}

Patterns Revealed from the Meta-Analysis. A total of $k$ $=123$ comparisons of male and female concentrations of mercury from 50 studies contributed to our data set (Table SI1). Most of the studies represented in our meta-analysis did not have the primary objective to study sex differences in the concentration of mercury; instead, values were reported by sex primarily for descriptive purposes. Thus, our data set is not likely biased to representing only significant sex differences. In fact, studies with positive, negative, and no difference in Hedges' $d$ effect sizes (reflecting magnitude and direction of sex differences) were represented in the data set (Figure 1). However, there were fewer studies with negative effect sizes, where females had higher concentrations of mercury. The six comparisons with the greatest negative effect sizes (Figure 1, Table SI-1) did not share any obvious similar qualities; there were different reproductive status categories (prebreeding,

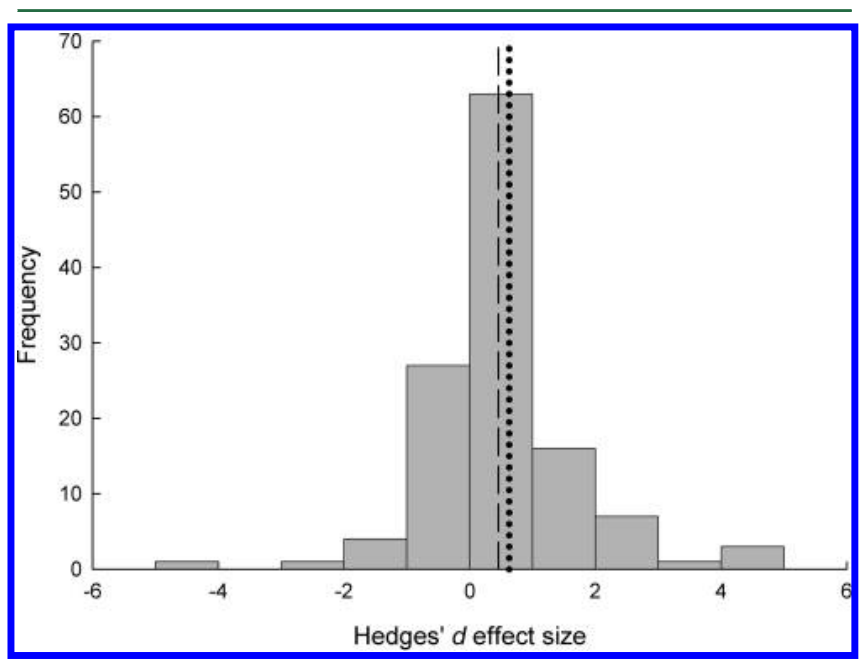

Figure 1. Histogram representing the frequencies of the calculated Hedges' $d$ effect sizes (differences between male and female concentrations of mercury) for all comparisons of sex differences in mercury concentration in birds used in our meta-analysis, with the mean effect size indicated by the dashed line. Mean effect size for breeding birds is indicated by a dotted line. Positive effect sizes indicate that males had higher concentrations of mercury than females. 
Table 2. Results from Random-Effects Meta-Analyses on Sex Differences in the Concentration of Mercury in Birds ${ }^{a}$

\begin{tabular}{|c|c|c|c|c|c|c|c|}
\hline data set & $k$ & $\bar{d}$ & $95 \% \mathrm{CI}$ & $\tau$ & $Q_{b}$ & $\mathrm{df}$ & $p$ \\
\hline all data & 123 & 0.458 & $0.335,0.581$ & 0.232 & & & \\
\hline tissue & & & & 0.249 & 1.025 & 2 & 0.599 \\
\hline blood & 46 & 0.518 & $0.333,0.704$ & & & & \\
\hline blood/liver & 16 & 0.497 & $0.155,0.838$ & & & & \\
\hline liver & 61 & 0.382 & $0.183,0.580$ & & & & \\
\hline reproductive status & & & & 0.256 & 11.50 & 2 & 0.003 \\
\hline breeding & 67 & 0.628 & $0.452,0.805$ & & & & \\
\hline prebreeding & 17 & 0.631 & $0.327,0.935$ & & & & \\
\hline nonbreeding & 21 & 0.005 & $-0.327,0.332$ & & & & \\
\hline hatchling status & & & & 0.230 & 2.23 & 1 & 0.135 \\
\hline altricial & 16 & 0.222 & $-0.112,0.555$ & & & & \\
\hline precocial & 107 & 0.495 & $0.363,0.628$ & & & & \\
\hline foraging guild & & & & 0.240 & 14.22 & 5 & 0.014 \\
\hline carnivore & 4 & 0.063 & $-0.643,0.769$ & & & & \\
\hline herbivore & 2 & -0.200 & $-1.261,0.862$ & & & & \\
\hline insectivore & 4 & 0.143 & $-0.458,0.744$ & & & & \\
\hline invertivore & 46 & 0.661 & $0.446,0.875$ & & & & \\
\hline omnivore & 11 & -0.150 & $-0.602,0.301$ & & & & \\
\hline piscivore & 56 & 0.490 & $0.309,0.662$ & & & & \\
\hline
\end{tabular}

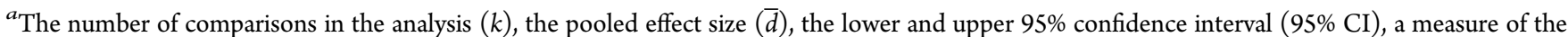
between-study variance included in random-effects models $(\tau)$, and the between-group test statistic $\left(Q_{b}\right)$ with its degrees of freedom $(\mathrm{df})$ and $p$-value are provided for each meta-analysis

breeding, nonbreeding, and not available), different degrees of sexual size dimorphism, and different foraging guilds (invertivore, omnivore, piscivore) represented.

We first determined that the overall mean effect size $(\bar{d})$ when all categories were analyzed together was significantly positive and nonzero $(\bar{d}=0.438$, Table 2$)$. Therefore, overall, male birds have a higher concentration of mercury than females. According to Cohen, ${ }^{39}$ this overall effect size is of moderate magnitude (i.e., small effect size $=0.2$, moderate effect size $=0.5$ and large effect size $=0.8)$. We then parsed the data by tissue and found that the effect sizes did not depend on the tissue categories (blood, liver, and blood/liver) suggesting that the tissue analyzed did not alter the occurrence of male birds having higher concentrations of mercury than females (Table 2). The addition of this moderator variable did not improve the amount of variation explained by the model beyond the basic no moderator model (based on differences in $\tau$ values; Table 2). For the remaining statistical comparisons, liver, blood, and blood/liver categories were all analyzed together.

We found that the reproductive status of the birds had a significant influence on the occurrence of a significant sex difference in the concentration of mercury in birds (Table 2). Breeding and prebreeding birds were found to have significant positive effects sizes, but nonbreeding birds did not have significant sex differences in effect sizes (Table 2). The confidence intervals for breeding and prebreeding birds overlapped, suggesting that that they did not differ from one another (Table 2); therefore, we combined prebreeding birds with the breeding birds category and parsed the data by reproductive status (i.e., breeding vs nonbreeding) for the relevant remaining analyses. First, we parsed the data by hatchling status and found the effect sizes did not depend on the hatchling status categories (altricial, precocial) suggesting that the proportion of yolk and albumen in an egg does not alter the occurrence of male birds having higher concentrations of mercury than females (Table 2). We then used an ANCOVA meta-regression model and found a significant difference in reproductive status but not in percentage of female body mass represented by the clutch or the interaction (Reproductive status: $Q=6.95, \mathrm{df}=1, p=0.008$; Clutch: $Q=0.14, \mathrm{df}=1, p=$ 0.705; Reproductive status $\times$ Clutch: $Q=0.30, \mathrm{df}=1, p=$ $0.583)$. When the nonsignificant interaction term was dropped from the model, the differences among breeding and nonbreeding birds remained, but the clutch mass as percentage of female body mass was still not a significant explanatory factor in our model (Figure 2; Reproductive status: $Q=11.07, \mathrm{df}=1$, $p<0.001$; Clutch: $Q=0.54, \mathrm{df}=1, p=0.461)$. Furthermore, a meta-regression found that variation in differences among male

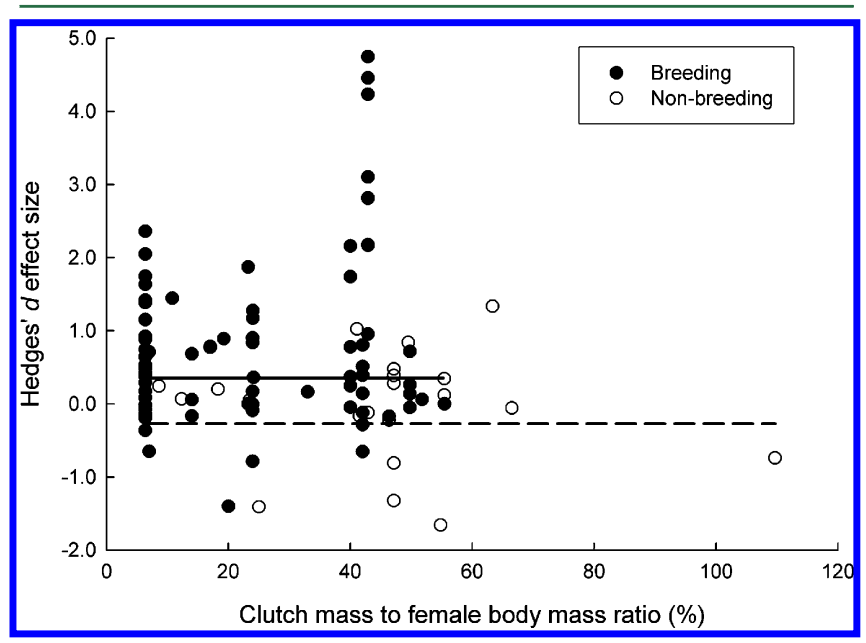

Figure 2. Null relationships for meta-regressions between Hedges' $d$ effect sizes (differences between male and female concentrations of mercury) and the percentage of female body mass represented by a clutch for breeding or nonbreeding birds. Regression lines based on meta-regression ANCOVA without the interaction term. Solid line represents meta-regression for breeding birds and dashed line represents meta-regression for nonbreeding birds. 
and female concentrations of mercury across all effect sizes could not be explained by the percentage of female body mass represented by a clutch for breeding birds $(k=78$, breeding only: $Q=0.81, \mathrm{df}=1, p=0.368)$.

We then determined if the degree of sexual size dimorphism influenced the occurrence of a sex difference in mercury concentration in birds. We used an ANCOVA meta-regression model and found a significant effect of reproductive status but not of male/female body mass ratio or the interaction (Reproductive status: $Q=10.53$, $\mathrm{df}=1, p=0.002$; male/ female body mass ratio: $Q=0.15$, $\mathrm{df}=1, p=0.694$; Reproductive status $\times$ male/female body mass ratio: $Q=0.01$, $\mathrm{df}=1, p=0.919$ ). When the nonsignificant interaction term was dropped from the model, the differences among breeding and nonbreeding birds remained, but the male/female body mass ratio was still not a significant explanatory factor in our model (Figure 3; Reproductive status: $Q=11.03$, $\mathrm{df}=1, p<$

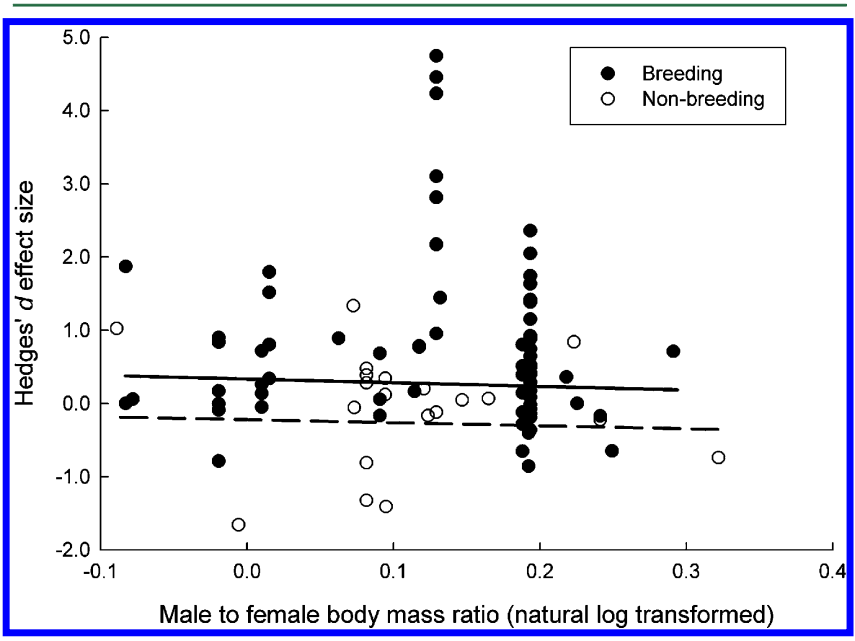

Figure 3. Null relationships for meta-regressions between Hedges' $d$ effect sizes (differences between male and female concentrations of mercury) and the body size ratio between male and female birds. Regression lines based on meta-regression ANCOVA without the interaction term. Solid line represents meta-regression for breeding birds and dashed line represents meta-regression for nonbreeding birds.

0.001; male/female body mass ratio: $Q=0.46, \mathrm{df}=1, p=$ 0.497). Furthermore, a meta-regression found that variation in differences among male and female concentrations of mercury across all effect sizes could not be explained by the male/female body mass ratio for breeding birds $(k=109$, breeding only: $Q=$ 0.29 , $\mathrm{df}=1, p=0.588$ ).

We also analyzed the influence of foraging guild on the detection of a sex difference in mercury. There were marginal nonsignificant differences between the six foraging guild categories (Table 2). Piscivores and invertivores were the most represented foraging guild in the data set and the only groups to reliably detect a significant difference in effect sizes between males and females, where males once again had higher concentrations of mercury than females (Table 2). Using a twoway ANOVA meta-analysis, and excluding insectivores because we did not have any information on the reproductive status, we found significant differences for reproductive status, but groups between foraging guilds did not differ, as well as the interaction term in our model (Reproductive status: $Q=0.73, \mathrm{df}=1, p=$ 0.393; Foraging guild: $Q=4.68, \mathrm{df}=4, p=0.321$; Reproductive status $\times$ Foraging guild: $Q=1.31, \mathrm{df}=4, p=0.859)$. When the nonsignificant interaction term was dropped from the analysis there were significant differences in reproductive status $(Q=$ $7.08, \mathrm{df}=1, p=0.008)$, and marginal significance in foraging guild $(Q=8.99, \mathrm{df}=4, p=0.061)$.

\section{DISCUSSION}

Primary Hypothesis: Depuration of Mercury to Eggs. We found significant sex differences in the concentration of mercury in birds, where males had higher concentrations than females. This corroborates expectations based on the explanation that females depurate mercury to their eggs and thus reduce their mercury body burden because only breeding birds were found to have significant sex differences in the concentration of mercury. However, the nonsignificant negative relationship between mercury differences among males and females and percentage of female body mass represented by a clutch is not consistent with what was expected based on the conventional explanation. Females that invest more of their body resources into producing a clutch should ceteris paribus have a greater capability to reduce their mercury body burden compared to females that do not invest as much into a clutch. Hence a significant positive relationship between sex differences in mercury and percentage of female body mass represented by the clutch was expected. Another related aspect is the occurrence of renesting by a species. We could not get renesting propensity for specific samples in our data set, however, some duck species, such as the mallard, Anas platyrhynchos, are celebrated renesters and samples included in our study do show very high effect sizes typically ranging from 2 to $>4$ (see Table SI-1). We also assessed hatchling status of a species and found it did not significantly influence the detection of a sex difference. Altricial species have proportionally more albumen in an $\operatorname{egg}^{22}$ and therefore a greater propensity for methylmercury depuration, given albumen has a greater affinity for methylmercury than yolk. ${ }^{23,24}$ The lack of a relationship with hatchling status strengthens the evidence that although egg depuration might explain sex biases in mercury, it does not explain why some species have a stronger sex bias than others.

The egg depuration hypothesis for sex differences in the concentration of mercury does make intuitive sense and indeed mercury is found in eggs ${ }^{40}$ and the concentrations of mercury in the eggs closely reflect female liver tissue concentrations in many species; ${ }^{8}$ however, the lack of support for egg depuration to account fully for a sex difference by Monteiro and Furness ${ }^{11}$ and by our meta-analysis suggests additional mechanisms may be operating. Importantly, there is a large amount of betweenstudy variation so it is possible that clutch size (i.e., clutch mass to female body mass ratio) is important but we were unable to detect it, in other words, failing to reject the null hypothesis. Notwithstanding, we expected to detect a weak but significant signal. There also are studies that suggest that mercury depurated to eggs can be replaced within days to weeks ${ }^{41,42}$ and thus affect our ability to relate clutch size to sex differences because we were not able to account for time of sampling beyond the coarse categories of breeding versus nonbreeding seasons. Our meta-analysis suggests mercury levels return to equilibrium between the sexes during the nonbreeding season. However, sex differences begin to be detectable again prior to egg-laying as shown by our initial assessment of prebreeding birds. Perhaps these prebreeding birds had initiated allocation of resources and thus methylmercury to egg production at the time of sampling which would support the egg depuration 
hypothesis. Alternatively, the sex difference detected during the prebreeding stage could be an indication that something other than egg-laying associated with breeding season (e.g., physiological/metabolic changes induced by hormones or foraging differences in preparation for breeding) might be influencing sex differences in methylmercury dynamics. Our research suggests future work should target specific questions within a species or within trophically related species. Of particular importance will be determining what is the effect of mercury depuration to a clutch on the occurrence and magnitude of a sex difference in this contaminant and how does time of sampling influence the detections of such sex differences in mercury? Simply performing another study documenting levels of mercury in males and females will not be particularly informative.

Ancillary Hypothesis I: Sexual Size Dimorphism and Exposure to Mercury. Another well-known explanation for a sex difference in mercury is the occurrence and direction of sexual size dimorphism. For example, differences in the concentration of mercury in adult loons (where males are larger than females) was explained by adult males consuming larger fish than females where larger fish often have greater body burdens of mercury than smaller fish; ${ }^{43}$ hence, male loons were likely more exposed to mercury than the females resulting in the sex difference in mercury. ${ }^{44}$ We addressed this sexual size dimorphism explanation by determining if the effect size (difference in concentration of mercury between males and females) differed by the male to female body mass ratio. We found no significant relationship between the effect size and the male/female body mass ratio therefore we conclude that sexual size dimorphism does not generally account for significant sex difference in concentration of mercury in birds. A sex difference in foraging or prey consumption, independent of sexual size dimorphism, might still influence the sex difference in concentration of mercury in individual species of birds. Females might selectively forage during the breeding season which could affect their exposure to mercury, particularly in comparison to males. ${ }^{45,46}$ This avenue of research might be especially fruitful in explaining some of the remaining variation in the sex differences in the concentration of mercury in birds.

Ancillary Hypothesis II: Foraging Guild and Detoxification of Methylmercury. Several studies have found a positive relationship between the concentration of mercury and trophic level. ${ }^{47,48}$ Mercury is a natural heavy metal, hence piscivores have likely always been the most exposed and are thought to have adapted to tolerate these toxic exposures over evolutionary time. ${ }^{49}$ For example, albatross are one of the longest lived aquatic birds that are highly exposed to mercury. ${ }^{50}$ Albatross have some of the highest concentrations of mercury found in presumably healthy and reproducing birds. ${ }^{50}$ It is thought albatross and indeed other seabirds have adapted by detoxifying and perhaps ridding their bodies of methylmercury more efficiently or to a greater degree than non fish-eating birds. ${ }^{49,50}$ Egg depuration is one way of ridding a female's body of mercury; however, embryos are particularly sensitive to mercury toxicity ${ }^{1}$ and therefore it would be maladaptive to dump large quantities of mercury into the eggs.

The liver is able to detoxify methylmercury by demethylating it to inorganic mercury. ${ }^{13}$ Eagles-Smith et al. ${ }^{15}$ found differences in the demethylation threshold and rate of demethylation in liver tissue between two taxonomic groups of birds (i.e., invertivores vs piscivores). Following from EaglesSmith et al., ${ }^{15}$ Robinson et al. ${ }^{10}$ postulated that male and female cormorants might differ in their capability to demethylate based on liver size differences between males and females. We found little evidence to suggest that the occurrence of a sex difference during the breeding season might be related predictably to foraging guild and perhaps a detoxification adaptation in species with high exposure to mercury (i.e., aquatic foragers, particularly piscivores). However, the near significant effect of foraging guild found detectable sex differences in mercury for only the aquatic foragers (i.e., invertivores and piscivores) (albeit these two groups also had the largest sample size for analyses and thus a greater ability to detect a difference). Based on our meta-analysis, we suggest future research should focus on physiological differences in mercury metabolism (toxicodynamics) because the foraging guild results suggest male and female invertivores and piscivores may be responding differently to methylmercury than male and female carnivores, herbivores, insectivores, and omnivores. For example, future work could focus on determining if there is sexual size dimorphism in liver size or sex differences in liver function, particularly for breeding birds when vitellogenesis is occurring.

We provided the first meta-analysis of avian sex differences in mercury, where a consensus was reached that, in breeding birds, males typically have higher concentrations of mercury than females. Some of the variation in sex differences in the concentrations of mercury appeared explained by moderator variables (i.e., reproductive status) and supports the conventional explanation (i.e., egg depuration of mercury burden by breeding females). However, not all species showed male bias in mercury burden during breeding and strength of the bias was unrelated to a measure of degree of expected depuration to eggs (clutch mass as a percentage of female body mass and also hatchling status). Furthermore, prebreeding birds showed similar sex differences in mercury to breeding birds which brings into question the importance of depuration of mercury into eggs for all species since prebreeding birds have not yet laid their eggs (but may have allocated the resources for egg production). Other moderator variables relating to exposure, affinity, or detoxification, of methymercury (i.e., sexual size dimorphism and foraging guild, respectively) had little explanatory power. Such factors might be deemed unimportant generally because their influence was swamped by heterogeneity between studies. This study, and several of the studies cited, suggest that sex differences in mercury burden are not simply the result of egg depuration, even though this important mode of excretion is restricted to one sex. Perhaps sex differences in exposure or detoxification will prove important for some species and not others.

It is clear that, until recently, sex of wildlife was rarely considered during biomonitoring studies but representation of males and females in samples likely influences variation in contaminant levels and thus effects seen across locations and between years. If sex is not considered, researchers might overestimate or more importantly underestimate the risk for toxic effects to species. Collaborations among ecologists, evolutionary biologists, physiologists, and toxicologists will be essential to fully understand the role for sex in the dynamics of mercury (and indeed other contaminants) in wildlife and the environment.

\section{ASSOCIATED CONTENT}

\section{Supporting Information}

A summary of the information from articles used in the metaanalysis and the meta-regression; calculated Hedges' $d$ effect 
size, its variance, and the sample size for each male-female comparison in Table SI-1. This information is available free of charge via the Internet at http://pubs.acs.org/.

\section{AUTHOR INFORMATION}

\section{Corresponding Author}

*E-mail: srobinsc@connect.carleton.ca; phone: 613-520-2600 ext. 3872; fax: 613-520-3539.

\section{Notes}

The authors declare no competing financial interest.

\section{ACKNOWLEDGMENTS}

We thank M. Zanuttig for her help in collecting information from the published literature and M. Mallory for donating the picture of a female common eider and her eggs for the TOC Art. Funding for this research was provided by an NSERC Discovery Grant to M.R.F. We thank three anonymous referees for improving the text and helping us target future research questions.

\section{REFERENCES}

(1) Weiner, J. G.; Krabbenhoft, D. P.; Heinz, G. H.; Scheuhammer, A. M. Ecotoxicology of mercury. In Handbook of Ecotoxicology, 2nd ed.; Hoffman, D. J., Rattner, B. A., Burton, J. G. A., Cairns, J. J., Eds.; CRC Press: Boca Raton, FL, 2003; pp 409-463.

(2) Scheuhammer, A. M.; Meyer, M. W.; Sandheinrich, M. B.; Murray, M. W. Effects of environmental methylmercury on the health of wild birds, mammals, and fish. Ambio 2007, 36, 12-18.

(3) Burger, J. A framework and methods for incorporating genderrelated issues in wildlife risk assessment: Gender-related differences in metal levels and other contaminants as a case study. Environ. Res. 2007, 104, 153-162.

(4) Peakall, D.; Burger, J. Methodologies for assessing exposure to metals: Speciation, bioavailability of metals, and ecological host factors. Ecotoxicol. Environ. Saf. 2003, 56, 110-121.

(5) Burger, J.; Diaz-Barriga, F.; Marafante, E.; Pounds, J.; Robson, M. Methodologies to examine the importance of host factors in bioavailability of metals. Ecotoxicol. Environ. Saf. 2003, 56, 20-31.

(6) Burger, J.; Fossi, C.; McClellan-Green, P.; Orlando, E. F. Methodologies, bioindicators, and biomarkers for assessing genderrelated differences in wildlife exposed to environmental chemicals. Environ. Res. 2007, 104, 135-152.

(7) Braune, B. M.; Gaskin, D. E. Mercury levels in Bonaparte's gulls (Larus philadelphia) during autumn molt in the Quoddy region, New Brunswick, Canada. Arch. Environ. Contam. Toxicol. 1987, 16, 539549.

(8) Lewis, S. A.; Becker, P. H.; Furness, R. W. Mercury levels in eggs, tissues, and feathers of herring gulls Larus argentatus from the German Wadden sea coast. Environ. Pollut. 1993, 80, 293-299.

(9) Ackerman, J. T.; Eagles-Smith, C. A.; Takekawa, J. Y.; Demers, S. A.; Adelsbach, T. L.; Bluso, J. D.; Miles, A. K.; Warnock, N.; Suchanek, T. H.; Schwarzbach, S. E. Mercury concentrations and space use of pre-breeding American avocets and black-necked stilts in San Francisco Bay. Sci. Total Environ. 2007, 384, 452-466.

(10) Robinson, S. A.; Forbes, M. R.; Hebert, C. E.; Scheuhammer, A. M. Evidence for sex differences in mercury dynamics in double-crested cormorants. Environ. Sci. Technol. 2011, 45, 1213-1218.

(11) Monteiro, L. R.; Furness, R. W. Kinetics, dose-response, and excretion of methylmercury in free-living adult Cory's shearwaters. Environ. Sci. Technol. 2001, 35, 739-746.

(12) Weiner, J. G.; Spry, D. J. Toxicological significance of mercury in freshwater fish. In Environmental Contaminants in Wildlife: Interpreting Tissue Concentrations; Beyer, W. N., Heinz, G. H., Redmon-Norwood, A. W., Eds.; Lewis Publishers: Boca Raton, FL; pp 297-339.

(13) Thompson, D. R.; Furness, R. W. The chemical form of mercury stored in south-Atlantic seabirds. Environ. Pollut. 1989, 60, 305-317.
(14) Kim, E. Y.; Murakami, T.; Saeki, K.; Tatsukawa, R. Mercury levels and its chemical form in tissues and organs of seabirds. Arch. Environ. Contam. Toxicol. 1996, 30, 259-266.

(15) Eagles-Smith, C. A.; Ackerman, J. T.; Yee, J.; Adelsbach, T. L. Mercury demethylation in waterbird livers: Dose-response thresholds and differences among species. Environ. Toxicol. Chem. 2009, 28, 568577.

(16) Hindell, M. A.; Brothers, N.; Gales, R. Mercury and cadmium concentrations in the tissues of three species of southern albatrosses. Polar Biol. 1999, 22, 102-108.

(17) Lajeunesse, M. J. Recovering missing or partial data from studies: A survey of conversions and imputations for meta-analysis. In Handbook of Meta-Analysis in Ecology and Evolution; Koricheva, J., Gurevitch, J., Mengersen, K., Eds.; Princeton University Press: Princeton, New Jersey, in press.

(18) Walter, S. D.; Yao, X. Effect sizes can be calculated for studies reporting ranges for outcome variables in systematic reviews. J. Clin. Epidemiol. 2007, 60, 849-852.

(19) Poole, A., Ed. The birds of North America online; Cornell Laboratory of Ornithology: Ithaca, NY, http://bna.birds.cornell.edu/ BNA/; 2005; Viewed 15 Jul 2011.

(20) Del Hoyo, J., Elliott, A., Sargatal, J., Christie, D. A., Eds. The Handbook of the Birds of the World; Lynx Edicions: Spain, 1992.

(21) Dunning, J. B., Jr., Ed. CRC Handbook of Avian Body Masses, 2nd ed.; CRC Press Taylor \& Francis Group: Boca Raton, FL, 2008.

(22) Ehrlich, P. R., Dobkin, D. S., Wheye, D., Eds.; The Birder's Handbook - A Field Guide to the Natural History of North American Birds; Simon \& Schuster Inc.: New York, NY, 1988.

(23) Tejning, S. Biological effects of methyl mercury Dicyandiamidetreated grain in the domestic fowl Gallus gallus L. Oikos 1967, 8 (Suppl), 1-116.

(24) Heinz, G. H.; Hoffman, D. J. Mercury accumulation and loss in mallard eggs. Environ. Toxicol. Chem. 2004, 23, 222-224.

(25) Hughes, M. R. Water-content of salt-glands and other avian tissues. Comp. Biochem. Physiol. 1974, 47, 1089-1093.

(26) Ohlendorf, H. M.; Lowe, R. W.; Kelly, P. R.; Harvey, T. E. Selenium and heavy-metals in San-Francisco Bay diving ducks. J. Wildl. Manage. 1986, 50, 64-70.

(27) Eagles-Smith, C. A.; Ackerman, J. T.; Adelsbach, T. L.; Takekawa, J. Y.; Miles, A. K.; Keister, R. A. Mercury correlations among six tissues for four waterbird species breeding in San Francisco Bay, California, USA. Environ. Toxicol. Chem. 2008, 27, 2136-2153.

(28) Hedges, L. V. Distribution theory for Glass's estimator of effect size and related estimators. J. Educ. Stat. 1981, 6, 107-128.

(29) Hedges, L. V. Estimation of effect size from a series of independent experiments. Psychol. Bull. 1982, 92, 490-499.

(30) Conover, M. R.; Vest, J. L. Concentrations of selenium and mercury in eared grebes (Podiceps nigricollis) from Utah's Great Salt Lake, USA. Environ. Toxicol. Chem. 2009, 28, 1319-1323.

(31) Conover, M. R.; Vest, J. L. Selenium and mercury concentrations in California gulls breeding on the Great Salt Lake, Utah, USA. Environ. Toxicol. Chem. 2009, 28, 324-329.

(32) Wayland, M.; Garcia-Fernandez, A. J.; Neugebauer, E.; Gilchrist, H. G. Concentrations of cadmium, mercury and selenium in blood, liver and kidney of common eider ducks from the Canadian arctic. Environ. Monit. Assess. 2001, 71, 255-267.

(33) Lajeunesse, M. J. On the meta-analysis of response ratios for studies with correlated and multi-group designs. Ecology 2011, 92, 2049-2055.

(34) Gleser, L. J.; Olkin, I. Stochastically dependent effect sizes. In Handbook of Research Synthesis; Cooper, H., Hedges, L. V., Eds.; Russell Sage Foundation: New York, 1994; pp 339-356.

(35) Rosenberg, M. S.; Adams, D. C.; Gurevitch, J. METAWIN: statistical software for meta-analysis, version 2.0; Sinauer Associates: Sunderland, MA, 2000.

(36) Viechtbauer, W. Conducting meta-analyses in $\mathrm{R}$ with the Metafor package. J. Stat. Softw. 2010, 36, 1-48.

(37) Lipsey, M. W.; Wilson, D. B. Practical Meta-Analysis; Sage Publications, Inc.: London, U.K., 2001. 
(38) SAS Institute Inc. JMP [computer program]. Version 9; Cary, NC; 1989-2011.

(39) Cohen, J. Statistical Power Analysis for the Behavioral Sciences; Academic Press: New York, 1969.

(40) Becker, P. H. Egg mercury levels decline with the laying sequence in Charadriiformes. Bull. Environ. Contam. Toxicol. 1992, 48, $762-767$.

(41) Furness, R. W., Greenwood, J. J. D. Birds as Monitors of Environmental Change; Chapman and Hall: New York, NY, 1993.

(42) Kambamandi-Dimou, A.; Kamarianos, A.; Kilikidis, S. Transfer of methylmercury to hens' eggs after oral administration. Bull. Environ. Contam. Toxicol. 1991, 46, 126-133.

(43) Thompson, D. R. Metal levels in marine vertebrates. In Heavy Metals in the Marine Environment; Furness, R. W., Rainbow, P. S., Eds.; CRC Press, Inc.: Boca Raton, FL, 1990; pp 143-182.

(44) Evers, D. C.; Kaplan, J. D.; Meyer, M. W.; Reaman, P. S.; Braselton, W. E.; Major, A.; Burgess, N.; Scheuhammer, A. M. Geographic trend in mercury measured in common loon feathers and blood. Environ. Toxicol. Chem. 1998, 17, 173-183.

(45) Becker, P. H.; Gonzalez-Solis, J.; Behrends, B.; Croxall, J. Feather mercury levels in seabirds at South Georgia: influence of trophic position, sex and age. Mar. Ecol.-Prog. Ser. 2002, 243, 261-269.

(46) Gonzalez-Solis, J.; Sanpera, C.; Ruiz, X. Metals and selenium as bioindicators of geographic and trophic segregation in giant petrels Macronectes spp. Mar. Ecol.-Prog. Ser. 2002, 244, 257-264.

(47) Braune, B. M. Comparison of total mercury levels in relation to diet and molt for 9 species of marine birds. Arch. Environ. Contam. Toxicol. 1987, 16, 217-224.

(48) Zolfaghari, G.; Esmaili-Sari, A.; Ghasempouri, S. M.; Baydokhti, R. R.; Kiabi, B. H. A multispecies-monitoring study about bioaccumulation of mercury in Iranian birds (Khuzestan to Persian Gulf): Effect of taxonomic affiliation and trophic level. Environ. Res. 2009, 109, 830-836.

(49) Thompson, D. R. Mercury in birds and terrestrial mammals. In Environmental Contaminants in Wildlife: Interpreting Tissue Concentrations; Beyer, W. N., Heinz, G. H., Redmon-Norwood, A. W., Eds.; CRC Press, Inc.: Boca Raton, FL, 1996; pp 341-356.

(50) Muirhead, S. J.; Furness, R. W. Heavy metal concentrations in the tissues of seabirds from Gough Island, South-Atlantic ocean. Mar. Pollut. Bull. 1988, 19, 278-283. 
1 A meta-analysis of sex differences in mercury contamination of birds challenges

2 conventional wisdom

3

4 Stacey A. Robinson ${ }^{1 *}$, Marc J. Lajeunesse ${ }^{2}$, and Mark R. Forbes ${ }^{1}$

5

6 Supporting Information consists of :

$7 \quad$ Table SI-1

$8 \quad$ Total pages : 11 
Table SI-1. Summary of the information from articles used in the meta-analysis and meta-regression and their estimated Hedges' $d$ effect size, and variance values. Note: ID represents the study source and the comparison number (i.e., source-comparison), where some studies provided more than one comparison for the meta-analysis and meta-regression; B_L represents pooled effect sizes for blood and liver tissues from the same individuals (see methods); Repro_stat represents reproductive status; SSD represents sexual size dimorphism where the values presented are the natural log transformed male to female body mass ratios; \%Clutch represents the ratio of clutch mass to female body mass; Hatch_stat represents hatchling status (semi-Preco = semi-precocial and semi-Altric=semialtricial) and NA represents that the information was not available in the literature. Total sample sizes (n) are indicated for each study (blood, liver $\mathrm{n}$ also provided for studies that measured both tissues).

\begin{tabular}{|c|c|c|c|c|c|c|c|c|c|c|}
\hline $\bar{D}$ & Species & Tissue & Repro_stat & SSD & Trophic & \%Clutch & Hatch_stat & d & var_d & $\mathrm{n}$ \\
\hline $1-1$ & Anas crecca & Liver & Non-breeding & 0.095 & Omnivore & 25 & Precocial & -1.41 & 0.46 & 12 \\
\hline $1-2$ & Bucephala albeola & Liver & Non-breeding & 0.322 & Invertivore & 109.7 & Precocial & -0.74 & 0.80 & 6 \\
\hline $1-3$ & Melanitta perspicillata & Liver & Non-breeding & 0.072 & Invertivore & 63.3 & Precocial & 1.34 & 0.31 & 10 \\
\hline $1-4$ & Melanitta fusca & Liver & Non-breeding & 0.223 & Invertivore & 49.5 & Precocial & 0.84 & 0.26 & 17 \\
\hline $2-5$ & Anas rubripes & Liver & Non-breeding & 0.241 & Herbivore & 46.35 & Precocial & -0.22 & 0.29 & 14 \\
\hline $2-6$ & Aythya marila & Liver & Non-breeding & 0.094 & Invertivore & 55.4 & Precocial & 0.34 & 0.34 & 16 \\
\hline $2-7$ & Anas platyrhynchos & Liver & Non-k & 0.129 & Invertivore & 42.9 & Precocial & -0.12 & 0.58 & 7 \\
\hline $3-8$ & Anas platyrhynchos & Liver & Breeding & 0.129 & Invertivore & 42.9 & Precocial & 2.17 & 0.64 & 12 \\
\hline $3-9$ & Anas platyrhynchos & Liver & Breeding & 0.129 & Invertivore & 42.9 & Precocial & 4.45 & 0.99 & 17 \\
\hline $3-10$ & Anas platyrhynchos & Liver & Breeding & 0.129 & Invertivore & 42.9 & Precocial & 2.81 & 0.64 & 17 \\
\hline $4-11$ & Anas platyrhynchos & Liver & Breeding & 0.129 & tivore & 42.9 & Precocial & 4.75 & 1.53 & 10 \\
\hline $4-12$ & Anas platyrhynchos & Liver & Bree & 0.129 & Invertivore & 42.9 & Precocial & 0.96 & 0.45 & 10 \\
\hline $4-13$ & Anas platyrhynchos & Liver & Breeding & 0.129 & Invertivore & 42.9 & Precocial & 3.10 & 0.88 & 10 \\
\hline $4-14$ & Anas platyrhynchos & Liver & Breeding & 0.129 & Invertivore & 42.9 & Precocial & 4.23 & 1.29 & 10 \\
\hline $5-15$ & ityrhynchos & Liver & Bre & 0.129 & vore & 42.9 & Pre & 2.17 & 0.64 & 12 \\
\hline $5-16$ & Anas platyrhynchos & Liver & Bre & 0.129 & vore & 42.9 & Pre & 2.82 & 0.74 & 13 \\
\hline $6-17$ & Anas rubripes & Liver & Breeding & 0.241 & Herbivore & 46.4 & Precocial & -0.17 & 0.41 & 16 \\
\hline $7-18$ & Aythya affinis & Liver & Non-breec & 0.073 & ivore & 66.5 & Precocial & -0.09 & 0.03 & 117 \\
\hline $8-19$ & lisineria & Liver & Non & 0.082 & Om & 47.1 & Prec & -2.40 & 0.72 & 18 \\
\hline $8-20$ & Aythya marila & Liver & Non-breeding & 0.094 & Invertivore & 55.4 & Precocial & 0.23 & 0.67 & 8 \\
\hline $9-21$ & Aythya valisineria & Liver & Non-breeding & 0.082 & Omnivore & 47.1 & Precocial & 0.85 & 0.44 & 10 \\
\hline $9-22$ & isineria & Liver & & 0.082 & Om & 47.1 & Prec & -1.13 & 0.46 & 10 \\
\hline $9-23$ & Aythya valisineria & Liver & Non-breeding & 0.082 & Omnivore & 47.1 & Precocial & 0.48 & 0.41 & 10 \\
\hline
\end{tabular}




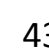

$45 \quad 10-25$ Calonectris diomedea

$46 \quad 10-26$ Calonectris diomedea

$47 \quad 10-27$ Calonectris diomedea

$48 \quad 11-28$ Cathartes aura

$49 \quad 12-29$ Catharus bicknelli

$50 \quad$ 12-30 Catharus bicknelli

51 12-31 Catharus bicknelli

$52 \quad 12-32$ Catharus bicknelli

53 13-33 Pluvialis squatarola

$54 \quad 13-34$ Catoptrophorus

55 semipalmatus

56 14-35 Tachycineta bicolor

$57 \quad 14-36$ Ceryle alcyon

58 14-37 Gavia immer

$59 \quad 15-38$ Clangula hyemalis

$60 \quad 15-39$ Clangula hyemalis

$61 \quad 15-40 \quad$ Clangula hyemalis

$62 \quad 15-41$ Clangula hyemalis

$63 \quad 15-42$ Clangula hyemalis

$64 \quad 15-43$ Clangula hyemalis

$65 \quad 15-44$ Clangula hyemalis

66 16-45 Egretta garzetta

$67 \quad$ 17-46 Eudyptula minor

$68 \quad 17-47$ Eudyptula minor

$69 \quad 18-48$ Falco sparverius

$70 \quad 19-49$ Fulmarus glacialis

$71 \quad 19-50$ Fulmarus glacialis

$72 \quad 20-51$ Gavia immer

73 20-52 Gavia immer

\begin{tabular}{|c|c|c|c|c|c|c|c|c|}
\hline$\overline{\text { Tissue }}$ & Repro stat & SSD & Trophic & \%Clutch & Hatch stat & $\bar{d}$ & var $d$ & $\mathrm{n}$ \\
\hline Liver & Non-breeding & 0.082 & Omnivore & 47.1 & Precocial & 0.68 & 0.42 & 10 \\
\hline Blood & Breeding & 0.091 & Piscivore & 14.0 & semi-Preco & 0.68 & 0.19 & 22 \\
\hline Blood & Breeding & 0.091 & Piscivore & 14.0 & semi-Preco & -0.17 & 0.18 & 22 \\
\hline Blood & Breeding & 0.091 & Piscivore & 14.0 & semi-Preco & 0.06 & 0.18 & 22 \\
\hline Liver & Non-breeding & NA & Carnivore & 8.6 & Altricial & 0.42 & 0.41 & 10 \\
\hline Blood & NA & -0.126 & Insectivore & NA & semi-Altric & 0.13 & 0.13 & 35 \\
\hline Blood & NA & -0.126 & Insectivore & NA & semi-Altric & -0.29 & 0.11 & 38 \\
\hline Blood & NA & -0.126 & Insectivore & NA & semi-Altric & 0.04 & 0.20 & 38 \\
\hline Blood & NA & -0.126 & Insectivore & NA & semi-Altric & 0.68 & 0.12 & 43 \\
\hline Liver & Non & -0.006 & Invertivore & 54.8 & Altricial & -1.66 & 0.55 & 10 \\
\hline Liver & Non- & -0.089 & Invertivore & 41.1 & Precocial & 1.02 & 0.53 & 10 \\
\hline Blood & NA & NA & Invertivore & 54 & Altricial & 0.12 & 0.11 & 50 \\
\hline Blood & NA & -0.054 & Piscivore & 44.5 & Altricial & -0.24 & 0.03 & 117 \\
\hline Blood & NA & 0.193 & Piscivore & 6.4 & semi-Preco & 0.21 & 0.01 & 770 \\
\hline Liver & Breeding & 0.188 & Invertivore & 42 & Precocial & -0.12 & 0.45 & 9 \\
\hline Liver & Breeding & 0.188 & Invertivore & 42 & Precocial & 0.51 & 0.64 & 10 \\
\hline Liver & Breeding & 0.188 & Invertivore & 42 & Precocial & -0.28 & 0.51 & 8 \\
\hline Liver & Breeding & 0.188 & Invertivore & 42 & Precocial & 0.14 & 0.42 & 10 \\
\hline Liver & Breeding & 0.188 & Invertivore & 42 & Precocial & 0.80 & 0.75 & 7 \\
\hline Liver & Breeding & 0.188 & Invertivore & 42 & Precocial & -0.66 & 0.73 & 7 \\
\hline Liver & Breeding & 0.188 & Invertivore & 42 & Precocial & 0.39 & 0.51 & 8 \\
\hline Liver & Breeding & NA & Piscivore & 20 & semi-Altric & -1.40 & 0.62 & 8 \\
\hline Liver & Breeding & 0.112 & Piscivore & NA & Altricial & 0.70 & 0.42 & 10 \\
\hline Liver & & 0.112 & Piscivore & NA & Altricial & 1.26 & 0.48 & 10 \\
\hline B_L & Breeding & -0.078 & Carnivore & 51.8 & Altricial & 0.06 & 0.91 & 4,4 \\
\hline Liver & Breeding & 0.118 & Piscivore & 17 & semi-Preco & 0.78 & 0.32 & 15 \\
\hline Liver & Breeding & 0.118 & Piscivore & 17 & semi-Preco & 0.77 & 0.29 & 15 \\
\hline Blood & Breeding & 0.193 & Piscivore & 6.4 & semi-Preco & 0.49 & 0.19 & 23 \\
\hline Blood & Breeding & 0.193 & Piscivore & 6.4 & semi-Preco & 1.64 & 0.55 & 10 \\
\hline
\end{tabular}


Table SI-1 (Continued)

\begin{tabular}{|c|c|c|c|c|c|c|c|c|c|c|}
\hline ID & Species & Tissue & Repro_stat & SSD & Trophic & $\%$ Clutch & Hatch_stat & $d$ & var_d & $\mathrm{n}$ \\
\hline $20-53$ & Gavia immer & Blood & Breeding & 0.193 & Piscivore & 6.4 & semi-Preco & 0.39 & 0.01 & 290 \\
\hline $20-54$ & Gavia immer & Blood & Breeding & 0.193 & Piscivore & 6.4 & semi-Preco & 1.42 & 0.19 & 27 \\
\hline $20-55$ & Gavia immer & Blood & Breeding & 0.193 & Piscivore & 6.4 & semi-Preco & 1.75 & 0.37 & 15 \\
\hline $20-56$ & Gavia immer & Blood & Breeding & 0.193 & Piscivore & 6.4 & semi-Preco & 2.05 & 0.36 & 17 \\
\hline $20-57$ & Gavia immer & Blood & Breeding & 0.193 & Piscivore & 6.4 & semi-Preco & -0.01 & 0.45 & 9 \\
\hline $20-58$ & Gavia immer & Blood & Breeding & 0.193 & Piscivore & 6.4 & semi-Preco & 1.15 & 0.14 & 35 \\
\hline $20-59$ & Gavia immer & Blood & Breeding & 0.193 & Piscivore & 6.4 & semi-Preco & 0.65 & 0.34 & 13 \\
\hline $20-60$ & Gavia immer & Blood & Breeding & 0.193 & Piscivore & 6.4 & semi-Preco & 0.53 & 0.12 & 35 \\
\hline $20-61$ & Gavia immer & Blood & Breeding & 0.193 & Piscivore & 6.4 & semi-Preco & 0.17 & 0.03 & 117 \\
\hline $20-62$ & Gavia immer & Blood & Breeding & 0.193 & Piscivore & 6.4 & semi-Preco & 0.88 & 0.21 & 22 \\
\hline $20-63$ & Gavia & Blood & Breeding & 0.193 & Piscivore & 6.4 & Preco & 0.75 & 0.15 & 30 \\
\hline $20-64$ & Gavia immer & Blood & Breeding & 0.193 & Piscivore & 6.4 & semi-Preco & -0.08 & 0.15 & 27 \\
\hline $21-65$ & Gavia immer & Liver & Breeding & 0.193 & Piscivore & 6.4 & semi-Preco & 0.49 & 0.04 & 107 \\
\hline $21-66$ & Gavia immer & Liver & Bree & 0.193 & Piscivore & 6.4 & semi-Preco & -0.31 & 0.18 & 23 \\
\hline $22-67$ & Gavia immer & Liver & NA & 0.193 & Piscivore & 6.4 & semi-Preco & 0.23 & 0.22 & 21 \\
\hline $23-68$ & nmer & Blood & Bre & 0.193 & Piscivore & 6.4 & Preco & 0.90 & 0.06 & 74 \\
\hline $23-69$ & Gavia immer & Blood & Breeding & 0.193 & Piscivore & 6.4 & semi-Preco & -0.36 & 0.12 & 34 \\
\hline $24-70$ & Gavia immer & Blood & Breeding & 0.193 & Piscivore & 6.4 & -Preco & 1.39 & 0.40 & 13 \\
\hline 24-71 & Gavi & Blood & Bre & 0.193 & Pisc & 6.4 & Preco & 2.36 & 1.39 & 5 \\
\hline $24-72$ & Gavia immer & Blood & Breeding & 0.193 & Piscivore & 6.4 & -Preco & -0.14 & 0.20 & 20 \\
\hline $24-73$ & Gavi & Blood & Bree & 0.193 & Pis & 6.4 & Preco & 0.08 & 0.10 & 42 \\
\hline $25-74$ & Gavi & Blood & & 0.193 & re & 6.4 & Preco & 0.90 & 0.37 & 12 \\
\hline $26-75$ & Gavis & Blood & Bre & 0.193 & Pisc & 6.4 & Preco & 0.65 & 0.24 & 18 \\
\hline $26-76$ & Gavi & Blood & Bre & 0.193 & Pisc & 6.4 & Preco & 0.42 & 0.11 & 40 \\
\hline $27-77$ & Gavic & Blood & & 33 & & 6.4 & Preco & 0.92 & 0.38 & 12 \\
\hline $27-78$ & Gavia & Blood & Bree & 0.193 & Piscivore & 6.4 & Preco & 0.91 & 0.43 & 11 \\
\hline $28-79$ & Grus japonensis & Liver & NA & NA & Omnivore & 7.2 & Precocial & 0.42 & 0.08 & 52 \\
\hline $29-80$ & Haematopus ostr & Blood & & NA & Invertivore & 24 & semi-Preco & 1.17 & 0.13 & 37 \\
\hline $29-81$ & Haematopus ostra & Blood & Breeding & NA & tivore & 24 & -Preco & 1.27 & 0.22 & 22 \\
\hline $30-82$ & Recurvirostra americana & Blood & Pre-breeding & 0.015 & Invertivore & NA & Precocial & 0.34 & 0.01 & 371 \\
\hline $30-83$ & Himantopus mexicanus & Blood & Pre-breeding & 0.010 & Invertivore & 49.8 & Precocial & 0.14 & 0.03 & 157 \\
\hline
\end{tabular}


Table SI-1 (Continued)

\begin{tabular}{|c|c|c|c|c|c|c|c|c|c|c|}
\hline $\mathrm{ID}$ & Species & Tissue & Repro_stat & SSD & Trophic & \%Clutch & Hatch_stat & d & var_d & $\mathrm{n}$ \\
\hline $31-84$ & Sterna forsteri & B_L & Pre-breeding & $\overline{\mathrm{NA}}$ & Piscivore & 40 & semi-Preco & 0.33 & 0.04 & 76,20 \\
\hline $31-85$ & Sterna forsteri & B_L & Pre-breeding & NA & Piscivore & 40 & semi-Preco & 0.13 & 0.20 & 21,15 \\
\hline $31-86$ & Sterna forsteri & B_L & Pre-breeding & NA & iscivore & 40 & i-Preco & 0.21 & 0.16 & 24,20 \\
\hline $31-87$ & Sterna forsteri & B_L & Breeding & NA & scivore & 40 & Preco & 0.78 & 0.15 & 29,29 \\
\hline $31-88$ & Sterna forsteri & B_L & Breeding & NA & Piscivore & 40 & semi-Preco & 2.16 & 0.48 & 13,13 \\
\hline $31-89$ & Hydroprogne caspia & B_L & Pre-breeding & -0.019 & ore & 24 & Preco & -0.00 & 0.76 & 5,5 \\
\hline $31-90$ & Hydroprogne caspia & B_L & eeding & -0.019 & Piscivore & 24 & Preco & -1.13 & 0.92 & 5,5 \\
\hline $31-91$ & Hydroprogne caspia & 1 & Pre-breeding & -0.019 & Piscivore & 24 & semi-Preco & 0.85 & 0.26 & 20 \\
\hline $31-92$ & Hydroprogne caspia & B_L & Bre & -0.0 & ore & 24 & Preco & 0.19 & 0.76 & 5,5 \\
\hline $31-93$ & Hydroprogne cas & B_L & Bre & -0.019 & Pisc & 24 & eco & -0.12 & 0.76 & 5,5 \\
\hline $31-94$ & Hydroprogne caspia & B_L & Breeding & -0.019 & Piscivore & 24 & Preco & 0.97 & 0.41 & 10,10 \\
\hline $31-95$ & Himantopus mexicanus & B_L & eding & 0.010 & jore & 49.8 & cial & 0.01 & 0.03 & 108,25 \\
\hline $31-96$ & Himantopus mexicanus & B_L & eding & 0.01 & vore & 49.8 & & 0.52 & 0.25 & 20,20 \\
\hline $31-97$ & Himantopus mexicanus & Blood & eding & 0.010 & vore & 49.8 & & 0.26 & 0.14 & 34 \\
\hline $31-98$ & Recurvirostra americ & B_L & ding & 0.0 & ore & NA & sial & 0.75 & $0.00 s$ & 336,4 \\
\hline $31-99$ & Recurvirostra americana & Liver & eding & 0.0 & jore & NA & & 1.79 & 0.46 & 22 \\
\hline $31-100$ & 0 Recurvirostra americana & B_L & eding & 0.0 & jore & NA & & 1.37 & 0.16 & 45,23 \\
\hline $32-101$ & rgentatus & Liver & B & 0.1 & & 33 & reco & 0.16 & 0.14 & 37 \\
\hline $33-102$ & 2 Larus atricilla & Liver & Non- & 0.124 & & 41. & reco & -0.17 & 0.10 & 40 \\
\hline $34-103$ & 3 Alle alle & Liver & NA & 0.047 & ore & 19.2 & reco & -0.99 & 0.73 & 8 \\
\hline 34104 & 4 Larus hyperbore & Liver & $\mathrm{N}$ & 0.2 & & 26.7 & eco & -4.25 & 2.64 & 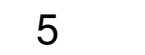 \\
\hline $34-105$ & 5 Larus hyperboreus & Liver & $\mathrm{N}$ & 0.2 & pre & 26.7 & reco & 0.39 & 0.71 & 7 \\
\hline $35-106$ & hectes halli & Blood & & 0.29 & & 7 & reco & 0.71 & 0.15 & 29 \\
\hline $35-107$ & $7 \mathrm{Macr}$ & Blood & & 0.24 & & 7 & reco & -0.65 & 0.13 & 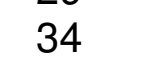 \\
\hline $36-108$ & 8 Pelecanus erythrorhyncos & Liver & NA & $0.24 i$ & & 6.3 & & 1.07 & 0.23 & 20 \\
\hline $37-109$ & 9 Phalacrocorax auritus & Liver & Bre & 0.132 & vore & 10.8 & al & 1.44 & 0.14 & 36 \\
\hline & caroo s & Liver & edin & 0.1 & & 12.3 & & 0.11 & 0.25 & 16 \\
\hline & yatis & Liver & & 0.218 & jore & 24.1 & & 0.62 & 0.23 & 18 \\
\hline & . & Liver & & 0.192 & & NA & & -0.86 & 0.31 & 16 \\
\hline & $3 P$ & Liver & Breeding & 0.192 & Piscivore & NA & Precocial & -0.40 & 0.22 & 20 \\
\hline
\end{tabular}


141 Table SI-1 (Continued)

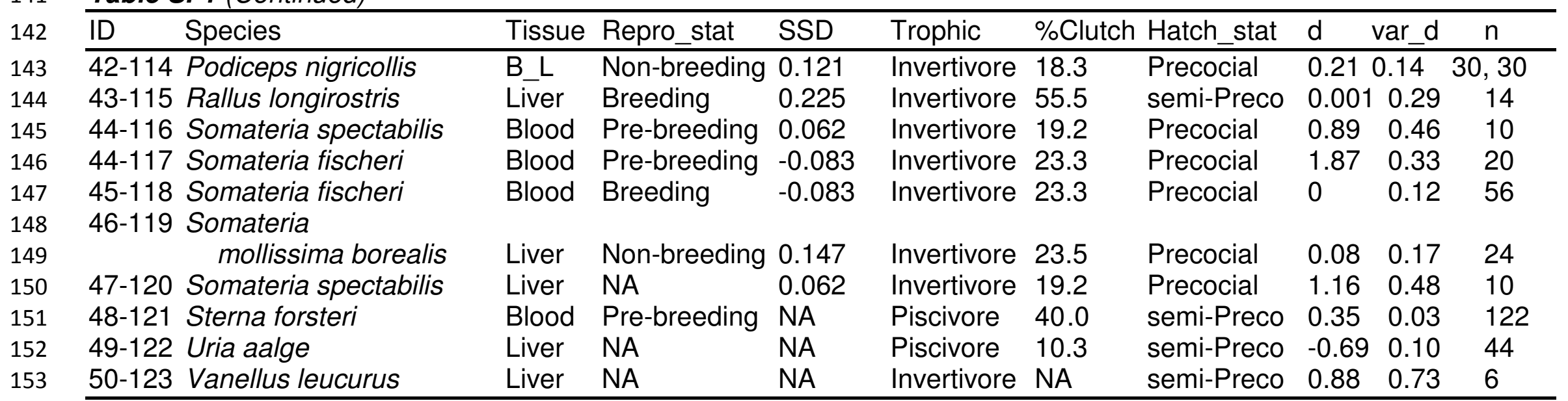




\section{Table SI-1 - References}

1. Braune, B. M.; Malone, B. J. Mercury and selenium in livers of waterfowl harvested in Northern Canada. Arch. Environ. Contam. Toxicol. 2006, 50, 284-289.

2. Gochfeld, M.; Burger, J. Heavy-metal concentrations in the liver of 3 duck species - influence of species and sex. Environ. Pollut. 1987, 45, 1-15.

3. Heinz, G. H. Methylmercury - reproductive and behavioural effects on 3 generations of mallard ducks. J. Wildl. Manage. 1979, 43, 394-401.

4. Heinz, G. H.; Hoffman, D. J. Methylmercury chloride and selenomethionine interactions on health and reproduction in mallards. Environ. Toxicol. Chem. 1998, 17, 139-145.

5. Heinz, G. H. Methylmercury - 2nd-year feeding effects on mallard reproduction and duckling behavior. J. Wildl. Manage. 1976, 40, 82-90.

6. Finley, M. T.; Stendell, R. C. Survival and reproductive success of black ducks fed methyl mercury. Environ. Pollut. 1978, 16, 51-64.

7. Pillatzki, A. E.; Neiger, R. D.; Chipps, S. R; Higgins, K. F.; Thiex, N.; Afton, A. D. Hepatic element concentrations of lesser scaup (Aythya affinis) during spring migration in the Upper Midwest. Arch. Environ. Contam. Toxicol. 2011, 61, 144-150.

8. Takekawa, J. Y.; Wainwright-De La Cruz, S. E.; Hothem, R. L.; Yee, J. Relating body condition to inorganic contaminant concentrations of diving ducks wintering in coastal California. Arch. Environ. Contam. Toxicol. 2002, 42, 60-70.

9. Fleming, W. J. Environmental metal residues in tissues of canvasbacks. J. Wildl. Manage. 1981, 45, 508-511.

10. Monteiro, L. R.; Furness, R. W. Kinetics, dose-response, and excretion of methylmercury in free-living adult Cory's shearwaters. Environ. Sci. Technol. 2001, 35, 739-746.

11. Wiemeyer, S. N.; Jurek, R. M.; Moore, J. F. Environmental contaminants in surrogates, foods, and feathers of California condors (Gymnogyps californianus). Environ. Monit. Assess. 1986, $6,91-111$.

12. Rimmer, C. C.; Miller, E. K.; McFarland, K. P.; Taylor, R. J.; Faccio, S. D. Mercury bioaccumulation and trophic transfer in the terrestrial food web of a montane forest. Ecotoxicology 2010, 19, 697-709.

13. Hui, C. A. Metal and trace element burdens in two shorebird species at two sympatric wintering sites in southern California. Environ. Monit. Assess. 1998, 50, 233-247. 
14. Evers, D. C.; Burgess, N. M.; Champoux L.; Hoskins, B.; Major, A.; Goodale, W. M.; Taylor, R. J.; Poppenga, R.; Daigle, T. Patterns and interpretation of mercury exposure in freshwater avian communities in Northeastern North America. Ecotoxicology 2005, 14, 193-221.

15. Braune, B. M.; Hobson, K. A.; Malone, B. J. Regional differences in collagen stable isotope and tissue trace element profiles in populations of long-tailed duck breeding in the Canadian Arctic. Sci. Total Environ. 2005, 346, 156-168.

16. Zamani-Ahmadmahmoodi, R.; Esmaili-Sari, A.; Savabieasfahani, M.; Bahramifar, N. Cattle egret (Bubulcus ibis) and Little egret (Egretta garzetta) as monitors of mercury contamination in Shadegan Wetlands of south-western Iran. Environ. Monit. Assess. 2010, 166, 371-377.

17. Choong, B.; Allinson, G.; Salzman, S.; Overeem, R.. Trace metal concentrations in the Little Penguin (Eudyptula minor) from Southern Victoria, Australia. Bull. Environ. Contam. Toxicol. 2007, 78, 53-57.

18. Bennett, R. S.; French, J. B.; Rossmann, R.; Haebler, R. Dietary toxicity and tissue accumulation of methylmercury in American kestrels. Arch. Environ. Contam. Toxicol. 2009, 56, 149-156.

19. Braune, B. M.; Mallory, M. L.; Butt, C. M.; Mabury, S. A.; Muir, D. C. G. Persistent halogenated organic contaminants and mercury in northern fulmars (Fulmarus glacialis) from the Canadian Arctic. Environ. Pollut. 2010, 158, 3513-3519.

20. Evers, D. C.; Kaplan, J. D.; Meyer, M. W.; Reaman, P. S.; Braselton, W. E.; Major, A.; Burgess, N.; Scheuhammer, A. M. Geographic trend in mercury measured in common loon feathers and blood. Environ. Toxicol. Chem. 1998, 17, 173-183.

21. Frank, R.; Lumsden, H.; Barr, J. F.; Braun, H. E. Residues of organochlorine insecticides, industrial-chemicals, and mercury in eggs and in tissues taken from healthy and emaciated common loons, Ontario, Canada, 1968-1980. Arch. Environ. Contam. Toxicol. 1983, 12, 641654.

22. Pokras, M. A.; Hanley, C.; Gordon, Z. Liver mercury and methylmercury concentrations in New England common loons (Gavia immer). Environ. Toxicol. Chem. 1998, 17, 202-204.

23. Burgess, N. M.; Meyer, M. W. Methylmercury exposure associated with reduced productivity in common loons. Ecotoxicology 2008, 17, 83-91.

24. Burgess, N. M.; Evers, D. C.; Kaplan, J. D. Mercury and other contaminants in common loons breeding in Atlantic Canada. Ecotoxicology 2005, 14, 241-252.

25. Scheuhammer, A. M.; Atchison, C. M.; Wong, A. H. K.; Evers, D. C. Mercury exposure in breeding common loons (Gavia immer) in central Ontario, Canada. Environ. Toxicol. Chem. 1998, 17, 191-196. 
26. Champoux, L.; Masse, D. C.; Evers, D.; Lane, O. P.; Plante, M.; Timmermans, S. T. A. Assessment of mercury exposure and potential effects on common loons (Gavia immer) in Quebec. Hydrobiologia 2006, 567, 263-274.

27. Meyer, M. W.; Evers, D. C.; Daulton, T.; Braselton, W. E. Common Loons (Gavia immer) nesting on low $\mathrm{pH}$ lakes in Northern Wisconsin have elevated blood mercury content. Water Air Soil Poll. 1995, 80, 871-880.

28. Teraoka, H.; Kumagai, Y.; Iwai, H.; Haraguchi, K.; Ohba, T.; Nakai, K.; Satoh, H.; Sakamoto, M.; Momose, K.; Masatomi, H.; Hiraga, T. Heavy metal contamination status of Japanese cranes (Grus japonensis) in East Hokkaido, Japan - extensive mercury pollution. Environ. Toxicol. Chem. 2007, 26, 307-312.

29. Goede, A. A.; Wolterbeek, H. T. Have high selenium concentrations in wading birds their origin in mercury. Sci. Total Environ. 1994, 144, 247-253.

30. Ackerman, J. T.; Eagles-Smith, C. A.; Takekawa, J. Y.; Demers, S. A.; Adelsbach, T. L.; Bluso, J. D.; Miles, A. K.; Warnock, N.; Suchanek, T. H.; Schwarzbach, S. E. Mercury concentrations and space use of pre-breeding American avocets and black-necked stilts in San Francisco Bay. Sci. Total Environ. 2007, 384, 452-466.

31. Eagles-Smith, C. A.; Ackerman, J. T.; De La Cruz, S. E. W.; Takekawa, J. Y. Mercury bioaccumulation and risk to three waterbird foraging guilds is influenced by foraging ecology and breeding stage. Environ. Pollut. 2009, 157, 1993-2002.

32. Lewis, S. A.; Becker, P. H.; Furness, R. W. Mercury levels in eggs, tissues, and feathers of herring gulls Larus argentatus from the German Wadden Sea Coast. Environ. Pollut. 1993, 80, 293-299.

33. Gochfeld, M.; Belant, J. L.; Shukla, T.; Benson, T.; Burger, J. Heavy metals in laughing gulls: gender, age and tissue differences. Environ. Toxicol. Chem. 1996, 15, 2275-2283.

34. Savinov, V. M.; Gabrielsen, G. W.; Savinova, T. N. Cadmium, zinc, copper, arsenic, selenium and mercury in seabirds from the Barents Sea: levels, inter-specific and geographical differences. Sci. Total Environ. 2003, 306, 133-158.

35. Gonzalez-Solis, J.; Sanpera, C.; Ruiz, X. Metals and selenium as bioindicators of geographic and trophic segregation in giant petrels Macronectes spp. Mar. Ecol.-Prog. Ser. 2002, 244, 257264.

36. Donaldson, G. M.; Braune, B. M. Sex-related levels of selenium, heavy metals, and organochlorine compounds in American white pelicans (Pelecanus erythrorhyncos). Arch. Environ. Contam. Toxicol. 1999, 37, 110-114. 
37. Robinson, S. A.; Forbes, M. R.; Hebert, C. E.; Scheuhammer, A. M. Evidence for sex differences in mercury dynamics in double-crested cormorants. Environ. Sci. Technol. 2011, 45, 1213-1218.

38. Platteeuw, M.; Vaneerden, M. R.; Vandeguchte, K. Variation in contaminant content of livers from cormorants Phalacrocorax carbo sinensis living nearby a polluted sedimentation area in Lake Ijsselmeer, the Netherlands. Ardea 1995, 83, 315-324.

39. Henny, C. J.; Herron, G. B. DDE, selenium, mercury, and white-faced ibis reproduction at Carson Lake, Nevada. J. Wildl. Manage. 1989, 53, 1032-1045.

40. Houserova, P.; Kuban, V.; Kracmar, S.; Sitko, J. Total mercury and mercury species in birds and fish in an aquatic ecosystem in the Czech Republic. Environ. Pollut. 2007, 145, 185-194.

41. Houserova, P.; Hedbavny, J.; Matejicek, D.; Kracmar, S.; Sitko, J.; Kuban, V. Determination of total mercury in muscle, intestines, liver and kidney tissues of cormorant (Phalacrocorax carbo), great crested grebe (Podiceps cristatus) and Eurasian buzzard (Buteo buteo). Vet. Med. 2005, 50, 61-68.

42. Conover, M. R.; Vest, J. L. Concentrations of selenium and mercury in eared grebes (Podiceps nigricollis) from Utah's Great Salt Lake, USA. Environ. Toxicol. Chem. 2009, 28, 1319-1323.

43. Cumbee, J. C.; Gaines, K. F.; Mills, G. L.; Garvin, N.; Stephens, W. L.; Novak, J. M.; Brisbin, I. L. Clapper rails as indicators of mercury and PCB bioavailability in a Georgia saltmarsh system. Ecotoxicology 2008, 17, 485-494.

44. Wilson, H. M.; Petersen, M. R.; Troy, D. Concentrations of metals and trace elements in blood of spectacled and king eiders in northern Alaska, USA. Environ. Toxicol. Chem. 2004, 23, 408-414.

45. Grand, J. B.; Franson, J. C.; Flint, P. L.; Petersen, M. R. Concentrations of trace elements in eggs and blood of spectacled and common eiders on the Yukon-Kuskokwim Delta, Alaska, USA. Environ. Toxicol. Chem. 2002, 21, 1673-1678.

46. Wayland, M.; Gilchrist, H. G.; Marchant, T.; Keating, J.; Smits, J. E. Immune function, stress response, and body condition in arctic-breeding common eiders in relation to cadmium, mercury, and selenium concentrations. Environ. Res. 2002, 90, 47-60.

47. Wayland, M.; Gilchrist, H. G.; Dickson, D. L.; Bollinger, T.; James, C.; Carreno, R. A.; Keating, J. Trace elements in king eiders and common eiders in the Canadian Arctic. Arch. Environ. Contam. Toxicol. 2001, 41, 491-500.

48. Ackerman, J. T.; Eagles-Smith, C. A.; Takekawa, J. Y.; Bluso, J. D.; Adelsbach, T. L. Mercury concentrations in blood and feathers of prebreeding Forster's terns in relation to space use of San Francisco Bay, California, USA, habitats. Environ. Toxicol. Chem. 2008, 27, 897-908. 
287 49. Debacker, V.; Holsbeek, L.; Tapia, G.; Gobert, S.; Joiris, C. R.; Jauniaux, T.; Coignoul, F.; 288 Bouquegneau, J. M. Ecotoxicological and pathological studies of common guillemots Uria aalge 289 beached on the Belgian coast during six successive wintering periods (1989-90 to 1994-95). Dis. 290 Aquat. Org. 1997, 29, 159-168.

291 50. Zamani-Ahmadmahmoodi, R.; Esmaili-Sari, A.; Savabieasfahani, M.; Ghasempouri, S. M.; 292 Bahramifar, N. Mercury pollution in three species of waders from Shadegan wetlands at the head 293 of the Persian Gulf. Bull. Environ. Contam. Toxicol. 2010, 84, 326-330. 